\title{
SEROPREVALENCE OF HEPATITIS B VIRUS INFECTION AMONG PATIENTS ATTENDING A TERTIARY CARE CENTRE IN NORTH-EAST INDIA
}

\author{
Ningombam Homendro Singh1, Rajkumar Manojkumar Singh², Huidrom Lokhendro Singh ${ }^{3}$, Yumlembam Bishwabati Devi ${ }^{4}$ \\ ${ }_{1}^{1}$ Postgraduate Student, Department of Microbiology, Jawaharlal Nehru Institute of Medical Sciences, Imphal, Manipur, India. \\ ${ }^{2}$ Associate Professor, Department of Microbiology, Jawaharlal Nehru Institute of Medical Sciences, Imphal, Manipur, India. \\ 3 Professor and HOD, Department of Microbiology, Jawaharlal Nehru Institute of Medical Sciences, Imphal, Manipur, India. \\ ${ }_{4}^{4}$ Microbiologist, Department of Microbiology, Jawaharlal Nehru Institute of Medical Sciences, Imphal, Manipur, India.
}

\section{BACKGROUND}

ABSTRACT

Hepatitis B infection is a major global health problem. The seroprevalence of Hepatitis B virus infection among general population attending at a tertiary care hospital is useful in assessing the magnitude of HBV infection and helps in devising preventive measures. The co-infection of Hepatitis B or Hepatitis C virus with HIV accelerates disease progression and may complicate the management of patients infected with HIV. This study was designed to determine hepatitis B virus infection among patients attending tertiary care centre in North-East India.

\section{MATERIALS \& METHODS}

A total of 11399 serum samples, collected from patients attending outpatient or inpatient departments and ART centre, were screened for HBsAg using 3rd generation ELISA (Qualisa HBsAg, Qualpro Diagnostics, Goa, India) in this retrospective study.

\section{RESULTS}

Seroprevalence of HBsAg was $1.23 \%$. Seropositivity was seen more in males $(2.2 \%)$ as compared to females $(0.89 \%)$. Among males, highest occurrence was found in the age group of 21-30 (3.29\%) years followed by 31-40 (2.94\%) years and 41-50 (2.37\%) years. Among females, highest prevalence was observed in age group of 51-60 (1.39\%) years followed by 61-70 (1.15\%) years and 41-50 (1.13\%) years.

\section{CONCLUSION}

Present study showed that the overall rate of HBsAg positivity in our center was $1.23 \%$. Males and younger age group were found to be more affected probably due to horizontal transmission.

\section{KEY WORDS}

ELISA, Hepatitis B, HBsAg, Sero-Prevalence.

HOW TO CITE THIS ARTICLE: Singh NH, Singh RM, Singh HL, et al. Seroprevalence of hepatitis b virus infection among patients attending a tertiary care centre in North-East India. J. Evolution Med. Dent. Sci. 2018;7(52):5506-5508, DOI: $10.14260 /$ jemds/2018/1218

\section{BACKGROUND}

Hepatitis B virus infection (HBV) is a common public health problem. About 2 billion people (or $30 \%$ of the world population) have serological evidence of current or past infection with hepatitis B virus. It is known to be the 10th leading cause of death and HBV related hepatocellular carcinoma is the 5 th most frequent cancer worldwide. ${ }^{[1]}$ An estimated 350 million people harbour chronic infection. The number of HBsAg carriers in India have been estimated to be over 40 million.[2] Major complications of chronic HBV infection are liver cirrhosis and primary cell carcinoma.

According to WHO and NCDC countries are classified as having high ( $8 \%$ or more), intermediate $(2-7 \%)$, or low (less than $2 \%$ ) HBV endemicity based on the prevalence of hepatitis B carrier state in the general population.

'Financial or Other Competing Interest': None.

Submission 14-11-2018, Peer Review 06-12-2018,

Acceptance 13-12-2018, Published 24-12-2018.

Corresponding Author:

Rajkumar Manojkumar Singh,

Associate Professor,

Department of Microbiology,

Jawaharlal Nehru Institute of Medical Sciences,

Imphal-795005, Manipur, India.

E-mail: rkmksingh@gmail.com

DOI: $10.14260 /$ jemds $/ 2018 / 1218$

\section{(c) $(1)(5)$}

India is at the intermediate endemic level of hepatitis $B$, with hepatitis B surface antigen prevalence between $2 \%$ and $7 \%$ among the populations studied.

The primary routes of transmission are perinatal, early childhood exposure, sexual contact, and per cutaneous exposure to blood or body fluids (i.e. injections, needle stick, blood transfusion). The hepatitis B surface antigen (HBsAg) in serum is the first sero-marker to indicate active HBV infection, either acute or chronic.[3]

The important source of infection is blood of a carrier. It is a heat stable and can survive outside the body for at least 7 days, as little as $0.00001 \mathrm{ml}$ of infected blood or infected material by Hepatitis B virus can be an infectious. The incubation period is 30 to 180 days. The virus may be detected within 30 to 60 days after infection and can persist and develop into chronic hepatitis B.[2] Virus may also be present in body fluids and excretions (Saliva, breast milk, semen, vaginal secretion, urine \& bile) and faces. A large population of patients suffering from hepatitis B may be asymptomatic and can transmit the disease to healthy population.

Human immunodeficiency virus (HIV), hepatitis B virus (HBV) and hepatitis C virus (HCV) have similar routes of transmission, namely through blood and blood products, sharing of needles to inject drugs and sexual activity.[4,5] Coinfection of $\mathrm{HBV}$ and $\mathrm{HCV}$ in HIV positive patients is 
associated with reduced survival and an increased risk of progression to severe liver diseases with higher susceptibility towards hepato-toxicity due to antiretroviral therapy.

The present study was undertaken to determine the seroprevalence of HBV infection among patients attending a tertiary care centre in North-East India and to assess the demographic profiles of seropositive patients/individuals. This study also aimed to highlight the presence of coinfection of HCV \& HIV, if any, among HBV infected patients.

\section{MATERIALS \& METHODS}

This is a hospital-based, retrospective descriptive study conducted in the department of Microbiology from July 2017 to June 2018. The study includes patients of all age groups \& both sexes attending various outpatient departments or admitted in the wards of medicine, surgery, orthopedics, obstetrics and gynaecology or pediatrics, who were undergoing HBsAg test as part of routine preoperative screening or for diagnostic purposes. HIV positive clients referred from ART centre for HBV and HCV screening were also included.

At least $5 \mathrm{ml}$ of blood was collected aseptically by venepuncture into sterile, disposable vials without anticoagulants and labelled with patient identification details. Serum was separated by centrifugation at a speed of 3000 rpm for 10 minutes and placed in sterile serum storage vials. All the serum samples were tested for HBsAg using $3^{\mathrm{rd}}$ generation ELISA (Qualisa HBsAg, Qualpro Diagnostics, Goa, India) following standard protocol and manufacturer's instructions with adequate quality control. Samples were considered reactive according to the manufacturer's specifications. However, any doubtful or indeterminate results were excluded from analysis. HBsAg positive samples were further subjected to qualitative detection of anti-HCV antibody using $3^{\text {rd }}$ generation ELISA (Qualisa HCV, Qualpro Diagnostics, Goa, India)

Analysis of data was done using descriptive statistics using such as percentage.

\section{RESULTS}

A total of 11399 serum samples were collected and processed for HBsAg during the study period of 12 months. Among these, 2901 (25.44\%) and 8498(74.55\%) were from male and female patients respectively (Table 1). The prevalence rate of HBV infection was found to be $1.23 \%$. The prevalence of hepatitis $\mathrm{B}$ virus infection was found to be higher amongst males $(2.2 \%)$ as compared to the female $(0.89 \%)$.

In this hospital-based study, highest occurrence of HBV infection among males was observed in age group of 21-30 $(3.29 \%)$ years followed by 31-40 (2.94\%) years and 41-50 $(2.37 \%)$ years (Table 2). Among females, highest prevalence was found in age group of 51-60 (1.39\%) years followed by $61-70(1.15 \%)$ years and $41-50(1.13 \%)$ years (Table 2$)$.

In this study, co-infection of HBsAg and HCV was observed in $0.096 \%(11 / 11399)$. HIV co-infection with HBsAg and HCV was seen in $1.6 \%$ and $19.1 \%$ respectively. The distribution of HBV and HCV co-infection in patients infected with HIV is shown in Table 3.

\begin{tabular}{|c|c|c|}
\hline Gender & Total No. of Sera Tested & HBsAg Positive (\%) \\
\hline Male & 2901 & $64(2.2)$ \\
\hline Female & 8498 & $76(0.89)$ \\
\hline Total & 11399 & $\mathbf{1 4 0 ( 1 . 2 3 )}$ \\
\hline \multicolumn{2}{|c|}{ Table 1. Gender Seroprevalence of HBsAg } \\
\hline
\end{tabular}

\begin{tabular}{|c|c|c|c|c|c|c|}
\hline $\begin{array}{c}\text { Age } \\
\text { Group } \\
\text { (Years) }\end{array}$ & $\begin{array}{c}\text { Total } \\
\text { Samples } \\
\text { Tested }\end{array}$ & \multicolumn{2}{|c|}{ Gender } & \multicolumn{2}{|c|}{ HBsAg +ve } & Total \\
\cline { 3 - 7 } & Male & Female & $\begin{array}{c}\text { Male } \\
(\%)\end{array}$ & $\begin{array}{c}\text { Female } \\
\text { HBsAg }\end{array}$ & $\begin{array}{c}\text { HBs } \\
\text { +ve })\end{array}$ \\
\hline $0-10$ & 284 & 178 & 106 & 0 & 0 & 0 \\
\hline $11-20$ & 1322 & 211 & 1111 & $\begin{array}{c}4 \\
(1.89)\end{array}$ & $\begin{array}{c}5 \\
(0.45)\end{array}$ & $\begin{array}{c}9 \\
(0.68)\end{array}$ \\
\hline $21-30$ & 3814 & 364 & 3450 & $\begin{array}{c}12 \\
(3.29)\end{array}$ & $\begin{array}{c}29 \\
(0.84)\end{array}$ & $\begin{array}{c}41 \\
(1.0)\end{array}$ \\
\hline $31-40$ & 2349 & 510 & 1839 & $\begin{array}{c}15 \\
(2.94)\end{array}$ & $\begin{array}{c}18 \\
(0.97)\end{array}$ & $\begin{array}{c}33 \\
(1.4)\end{array}$ \\
\hline $41-50$ & 1474 & 590 & 884 & $\begin{array}{c}14 \\
(2.37)\end{array}$ & $\begin{array}{c}10 \\
(1.13)\end{array}$ & $\begin{array}{c}24 \\
(1.62)\end{array}$ \\
\hline $51-60$ & 1025 & 451 & 574 & $\begin{array}{c}9 \\
(1.99)\end{array}$ & $\begin{array}{c}8 \\
(1.39)\end{array}$ & $\begin{array}{c}17 \\
(1.65)\end{array}$ \\
\hline $61-70$ & 708 & 361 & 347 & $\begin{array}{c}7 \\
(1.93)\end{array}$ & $\begin{array}{c}4 \\
(1.15)\end{array}$ & $\begin{array}{c}11 \\
(1.55)\end{array}$ \\
\hline$>70$ & 423 & 236 & 187 & $\begin{array}{c}3 \\
(1.27)\end{array}$ & $\begin{array}{c}2 \\
(1.06)\end{array}$ & $\begin{array}{c}5 \\
(1.18)\end{array}$ \\
\hline Total & $\mathbf{1 1 3 9 9}$ & $\mathbf{2 9 0 1}$ & $\mathbf{8 4 9 8}$ & $\begin{array}{c}\mathbf{6 4} \\
(\mathbf{2 . 2})\end{array}$ & $\begin{array}{c}\mathbf{7 6} \\
(\mathbf{0 . 8 9})\end{array}$ & $\begin{array}{c}\mathbf{1 4 0} \\
(\mathbf{1 . 2 3})\end{array}$ \\
\hline
\end{tabular}

Table 2. Age \& Gender Distribution of Screened Samples

\begin{tabular}{|c|c|c|c|}
\hline Gender & HIV +ve & HBsAg +ve & Anti HCV Ab +ve \\
\hline Male & 99 & $1(1.2 \%)$ & $29(29.29 \%)$ \\
\hline Female & 115 & $2(1.9 \%)$ & $12(10.4 \%)$ \\
\hline Total & $\mathbf{2 1 4}$ & $\mathbf{3}(1.6 \%)$ & $\mathbf{4 1}(19.1 \%)$ \\
\hline \multicolumn{2}{|r|}{ Table 3. Co-Infection of HIV with HBV \& HCV } \\
\hline
\end{tabular}

\section{DISCUSSION}

A total of 11399 serum samples tested for detection of HBsAg. Sero-prevalence of HBsAg in our center is $1.23 \%$ which is lower than most of the Indian studies (2-8\%). Sharma et al. have reported the prevalence of $2.31 \%$ among general population attending OPD at a tertiary care hospital.[6]

In this present study, higher HBV prevalence was observed among in males $(2.2 \%)$ as compared to the females $(0.89 \%)$ in females. Findings were in concordance with other earlier studies. [7-11] Patel et al. showed the intermediate level of prevalence of $2.67 \%$, in younger age group affecting more males. [11] Male predominance of HBsAg virus infection as compared with the female might be probably due to the higher exposure of male to occupational HBV indicating horizontal transmission, which may be due to unsafe injection practices, intravenous drug abuse, unsafe sexual practices and also probably because females clear the HBV more efficiently as compared to males. [2,12]

Among males, highest occurrence was found in age group of $21-30(3.29 \%)$ yrs. followed by $31-40(2.94 \%)$ yrs and $41-$ $50(2.37 \%)$ yrs. Similar results were noted by Sood et al and Patel et al. [8, 11] However, Tripathi et al observed highest prevalence in 31-40 years followed by 21-30 years, so it can be concluded that highest prevalence in 21-40 years indicating horizontal transmission.[10]

Among females, highest prevalence was found in age group of $51-60(1.39 \%)$ years followed by $61-70$ (1.15\%) years and $41-50(1.13 \%)$ years Similar results were noted by Patil et al and Quadri et al.[13,14] 
In our study, co-infection of HBV and HCV was observed in $0.096 \%$ which was lower than that of Desikan et al (1.89\%).[15] Of the total 214 HIV infected individuals included in our study, co-infection with HBV and HCV was found in $1.6 \%$ and $19.1 \%$ respectively. The higher prevalence rate of HCV in HIV positive patients in comparison to the rate for HBV positivity in HIV infected patients in our centre could be attributed to diverse factors such as increase in the rate of drug addiction, lack of vaccine for HCV. However, co-infection of HIV was noticed more in HBV rather than HCV in most of the Indian studies.[16,17]

\section{CONCLUSION}

Seroprevalence of Hepatitis B infection (1.23\%) was found to be slightly lower when compared to other parts of the country. Males especially in younger age group were found to be more affected. Our study re-emphasizes need for adequate public awareness to tackle this silent epidemic by improving prevailing health care practices and proper counselling.

\section{REFERENCES}

[1] Prevention of Hepatitis B in India - an overview. World Health Organization South-East Asia Regional Office, New Delhi, 2002.

[2] World Health Organization. Hepatitis B. World Health Organization Fact Sheet No. 204 (Updated July 2015). http://www.who.int/mediacentre/factsheets/fs204/e n/ (Last accessed on July 2017)

[3] Cariappa MP, Jayaram J, Bhalwar $\mathrm{R}$, et al. Epidemiological differentials of Hepatitis B carrier state in the army: a community based seroepidemiological study. Med J Armed Forces India 2004;60(3):251-4.

[4] Saravanan S, Velu V, Kumarasamy N, et al. Co-infection of hepatitis B and hepatitis C virus in HIV-infected patients in South India. World J Gastroenterol 2007;13(37):5015-20.

[5] Mohammad M, Talel G, Sheikhian A, et al. Survey of both hepatitis $B$ virus (HBsAg) and hepatitis $C$ virus (HCV-Ab) co-infection among HIV positive patients. Virol J 2009;6:202.

[6] Sharma M, Bohra S, Mehra SK, et al. Seroprevalence of Hepatitis B virus infection among OPD patients attending tertiary care hospital. Int Arch BioMed Clin Res 2017;3(2):51-3.
[7] Karki S, Ghimire P, Tiwari BR, et al. Trends in hepatitis $\mathrm{B}$ and hepatitis C seroprevalence among Nepalese blood donors. Jpn J Infect Dis 2008;61(4):324-6.

[8] Singh K, Bhat S, Shastry S. Trend in seroprevalence of hepatitis B virus infection among blood donors of coastal Karnataka, India. J Infect Dev Ctries 2009;3(5):376-9.

[9] Sood S, Malvankar S. Seroprevalence of Hepatitis B surface antigen, antibodies to the Hepatitis C virus, and Human Immunodeficiency Virus in a hospitalbased population in Jaipur, Rajasthan. Indian J Community Med 2010;35(1):165-9.

[10] Tripathi PC, Chakraverti TK, Khant NR. Seroprevalence of hepatitis B surface antigen and antibody to hepatitis $\mathrm{C}$ virus at a tertiary care centre in Telangana. Int J Res Med Sci 2015;3(1):297-300.

[11] Patel PH, Nerurkar AB, Patel MR. Seroprevalence of Hepatitis B surface antigen in patients attending a tertiary care hospital Valsad, South Gujarat, India. Int J Med Microbiol Trop Dis 2016;2(3):103-6.

[12] London WT, Drew JS. Sex differences in response to hepatitis B infection among patients receiving chronic dialysis treatment. Proc Natl Acad Sci USA 1977;74(6):2561-3.

[13] Patil SR, Ghorpade MV, Patil SS, et al. Seroprevalence of Hepatitis - B surface antigen among the patients reporting at tertiary care hospital from India. Bangladesh J Med Sci 2016;15(3):455-9.

[14] Quadri SA, Dadapeer HJ, Arifulla MK, et al. Prevalence of Hepatitis B surface antigen in hospital based population in Bijapur, Karnataka. Al Ameen J Med Sci 2013;6(2):180-2.

[15] Desikan P, Khan Z. Prevalence of hepatitis B and hepatitis $C$ virus co-infection in India: a systematic review and meta-analysis. Indian J Med Microbiol 2017:35(3)332-9.

[16] Ahuja S, Malhotra S, Chauhan A, et al. Seroprevalence of Hepatitis B and C co-infection in HIV positive patients from a tertiary care hospital. J Int Med Sci Acad 2013;26(2):91-2.

[17] Tripathi AK, Khanna M, Gupta N, et al. Low prevalence of Hepatitis B virus and Hepatitis C virus co-infection in patients with human immunodeficiency virus in Northern India. J Assoc Physicians India 2007;55:42931. 